\title{
HISTAMINE LEVELS IN FISH SAMPLES COLLECTED FROM SERBIAN MARKET IN 2018
}

\author{
Marija S. Pavlović ${ }^{1}$, Snežana D. Ivanović ${ }^{1}$, Ivan N. Pavlović ${ }^{1}$, Nikola I. Rokvić ${ }^{1}$, Vladimir I. \\ Radosavljević ${ }^{1}$, Dragan D. Vasilev ${ }^{2}$ \\ ${ }^{1}$ Scientific Institute of Veterinary Medicine of Serbia, 11000 Belgrade, Vojvode Toze 14, Serbia \\ ${ }^{2}$ University of Belgrade, Faculty of Veterinary Medicine, Department of Food Hygiene and \\ Technology, 11000 Belgrade, Bulevar oslobodjenja 18, Serbia
}

\author{
*Corresponding author: Marija Pavlović \\ Phone: +381112601141 \\ E-mail address: majaspavlovic@gmail.com
}

\begin{abstract}
Histamine is a biogen amin, which is formed by decarboxylation of the histidine amino acid, under the action of the L-histidine-decarboxylase enzyme. High level of free histidine in fish meat, bacterial histidin decarboxylase activity and high temperature of storage elevate the level of histamine. Among the most important factors that can affect the level of histamine in fish meat are the type of fish and the method of its preservation. In order to determine this dependence, 1030 samples of frozen fish (tuna, mackerel, sardines and sprat) and 167 samples of canned fish (tuna, sardines and mackerel) were monitored for histamine content by ELISA method. It was determined a lower concentration of histamine in frozen fish (from $5.71 \mathrm{mg} / \mathrm{kg}$ to $18.03 \mathrm{mg} / \mathrm{kg}$ ) compared to canned fish (from $15.03 \mathrm{mg} / \mathrm{kg}$ to $110.6 \mathrm{mg} / \mathrm{kg}$ ). The highest histamine concentrations were found in the mackerel samples, regardless of the preservation method $(110.6 \mathrm{mg} / \mathrm{kg}$ in canned mackerel and $18.03 \mathrm{mg} / \mathrm{kg}$ in frozen mackerel), which were significantly higher compared to the histamine levels found in cans of tuna and sardines $(p<0.0001)$. Of the total number of samples, three samples (two samples of canned sardines and one sample of canned mackerel) were declared unsafe for human health. In most of the analyzed samples, the level of determined histamine was relatively low, which confirms adequate implementation of control protocols and efficant surveillance of products placed on the Serbian market.
\end{abstract}

Key words: canned fish, frozen fish, tuna, sardines, mackerel, safety

\section{INTRODUCTION}

Histamine is a bioactive amine, which consist of imidazole ring with two nitrogen atoms and the aliphatic amino group. Endogenous histamine has significant physiological effects (has a role of a mediator, neurotransmitter and tissue hormone), thus takes part in vasodilatation, anaphylaxis, neurotransmission, gastric secretion, etc. Ingestion of high amounts of histamine cause scombrotoxin reactions, often called histamine poisoning. Histamine is synthetized in decarboxylation of the amino acid histidine, and reaction is catalyzed by the enzyme L-histidine decarbo- xylase. The ability to produce the enzyme have certain bacteria, and the most common are Escherichia coli, Morganella morganii, Proteus spp., Klebsiella pneumoniae, Hafnia alvei... (Lehanea and Olleyb, 2000; Özogul et al., 2017). Histamine-forming bacteria are capable of growing and producing histamine over a wide temperature range, but high temperature promotes the histamine synthesis. Thus, inadequate cooling of fish during storage elevates the histamine concentration. Therefore, histamine is considered to be a chemical indicator of a spoilage or decomposition pro- 
cess (Kaufman and Maden, 2017; Li et al., 2017). Once present in fish meat the enzyme remains active even if the bacteria are not active. Histidine decarboxylase enzyme remains stable in the frozen state, although the enzyme-forming bacteria are inactivate. Both the enzyme and the bacteria can be inactivated by cooking. However, once produced in fish meat histamine remains active regardless of the applied temperature. Histamine level that is considered to be permissible in fish and fishery products differs by country. In USA, histamine level of $50 \mathrm{mg} / \mathrm{kg}$ is an indicator of fish decomposition (FDA, 1995). The EU has established an acceptable level of histamine of $200 \mathrm{mg} / \mathrm{kg}$ for fish belonging to Scombridae, Clupeidae, Engraulidae, Coryphaenidae, Pomatomidae and Scomberesocidae families (Commission Regulation (EU) No. 2073/2005/EC). In Serbia, the current regulation regarding histamine content in fish meat has been harmonized with EU recommendations (Pravilnik, 2010; Pravilnik, 2018).

The aim of this study was to determine the level of histmine in canned fish and frozen fish of different species, commercily available on Serbian market, but also to compare it with regulatory standards.

\section{MATERIALS AND METHODS}

\section{Sampling and measurements}

A total of 167 samples of canned fish and 1030 samples of frozen fish were collected during the period of six months from the January 2018 to June 2018, as a part of official control. The weight of samples was approximately 500 grams.

The samples were collected before the expiration date. All samples of canned fish were free from any physical damage and were stored at room temperature in their original packaging until analysis. The samples of commercially available fish on Serbian market of frozen fish were stored on $20{ }^{\circ} \mathrm{C}$ until further analyses.

Histamine determination was performed by ELISA method. $10 \mathrm{~g}$ of fish sample was homogenized with $50 \mathrm{ml}$ of $0.1 \mathrm{M} \mathrm{HCL}$ for $5 \mathrm{~min}$. The homogenate was centrifuged at $3000 \mathrm{rpm}$ for $10 \mathrm{~min}$, after which three phases were separated: upper fatty phase, medium aqueous phase and precipitate. By $500 \mu \mathrm{l}$ of the homogenate from the aqueous phase was diluted with $500 \mu \mathrm{l}$ of solution for dilution, and then incubated with $50 \mu \mathrm{l}$ of the reaction solution and 200 $\mu \mathrm{l}$ of the neutralization solution.

After this preparation, the samples can be tested with ELISA method. The required chemicals and reagents for analyses are included in the kit, containing the necessary reagents for 96 samples. The analysis was performed in duplicate by procedure and recommendation of the manufacturer (Test Instruction HIS-EO01, 2008). The evolving of sample coloration in microtiter plate was measured photometrically at $450 \mathrm{~nm}$ microtiter plate reader. The histamine concentration is inversely proportional to the optical density of the samples and the standard. The limit of detection (LOD) and limit of quantification (LOQ) were $2.5 \mathrm{mg} / \mathrm{kg}$.

\section{Statistical analysis}

Data were analyzed by using GraphPad Prism software (2012). All the samples were analyzed as individual samples, i.e. the individual sample served as experimenttal unit for statistical analysis. Oneway ANOVA with Tukey's post-hoc test was performed to assess the significance of differences among experimental groups. Levels of $P<0.05$ and $P<0.001$ were considered as significant and highly significant, respectively.

\section{RESULTS AND DISCUSSION}

\section{Histamine levels in frozen fish}

Histamine was not detected in 103 of total 167 samples of frozen fish i.e. in the $61.67 \%$ of total number of samples histamine concertation was below the LOD $(2.5 \mathrm{mg} / \mathrm{kg})$. The histamine concentration varied from $3.17 \mathrm{mg} / \mathrm{kg}$ to $29.84 \mathrm{mg} / \mathrm{kg}$ in frozen fish samples. The overall mean of histamine concentrations in frozen fish samples considering every sample analyzed, regardless to species was 9.94 $\mathrm{mg} / \mathrm{kg}$. The details of histamine concentration detected for individual fish species are given in Table 1. 
Among individual fish species the highest level of histamine was detected in frozen mackerel $18.03 \mathrm{mg} / \mathrm{kg}$. The difference was statistically significant compared to histamine level in frozen tuna $(5.71 \mathrm{mg} / \mathrm{kg})$ and frozen sprat $(5.77 \mathrm{mg} / \mathrm{kg})$ at the level of 95\% $(P<0.05)$.

Determined levels of histamine in frozen fish samples were relatively low, and high proportion of samples had histamine concentration below LOD. In this trial, histamine was not detected in $64.91 \%$ of tuna samples, $42.86 \%$ of sardine samples, $65.62 \%$ of mackerel samples and $67.35 \%$ of sprat samples.

These results are higher than the results of Yesudhason et al. (2013) who reported histamine levels below $1 \mathrm{mg} / \mathrm{kg}$ in $38 \%$ of frozen fish samples histamine and Auerswald et al. (2006) who showed the portion of $39 \%$ of samples with histamine level below the LOD. However, the LOD in these trials were different and lower than in our study.

\section{Histamine levels in canned fish}

In 846 samples of canned fish of the total 1030 samples histamine level was below the LOD i.e. in the 456 samples of canned tuna, 315 samples of canned sardine and 75 samples of canned mackerel. The level of histamine varied between 2.90 to $365.50 \mathrm{mg} / \mathrm{kg}$ in canned fish, regardless to species.

The overall mean of all analyzed samples was $44.96 \mathrm{mg} / \mathrm{kg}$. The highest level of histamine was detected in the canned mackerel and was statistically higher compared to canned tuna and canned sardine $(p<0.0001)$. Between the tuna and sardine, the observed differences were significant at the level of $99 \%(p<0.001)$ (Table 2).

Some other authors (Vaciana-Nouges et al., 1997; Rahimi et al., 2012) observed the same trend. In contrast, Yesudhason et al. (2013) reported the highest level of histamine in tuna samples $(22.9 \mathrm{mg} / \mathrm{kg})$, followed by sardine with $12.3 \mathrm{mg} / \mathrm{kg}$ of

Table 1.

Histamine levels in frozen fish species

\begin{tabular}{lccc}
\hline Fish species & No of samples & $\begin{array}{c}\text { Histamine level } \\
(\mathbf{m g} / \mathbf{k g})\end{array}$ & $\begin{array}{c}\text { Interval of variation } \\
(\mathbf{m g} / \mathbf{k g})\end{array}$ \\
\hline Tuna & 57 & $5.71 \pm 1.15^{\mathrm{a}}$ & $3.17-8.24$ \\
Sardine & 28 & $9.88 \pm 2.65^{\mathrm{ns}}$ & $4.04-15.73$ \\
Mackerel & 33 & $18.03 \pm 5.36^{\mathrm{a}, \mathrm{b}}$ & $6.23-29.84$ \\
Sprat & 49 & $5.77 \pm 0.84^{\mathrm{b}}$ & $3.89-7.65$ \\
\hline Total & 167 & $9.94 \pm 1.69$ & $3.17-29.84$ \\
P value (ANOVA) & & $<0.05$ & \\
\hline
\end{tabular}

Values are expressed as mean $\pm S D$

a,b Means with same superscript within the column differ significantly at $P<0.05$

${ }^{n s}$ Non significant

Table 2.

Histamine level in canned fish species

\begin{tabular}{lccc}
\hline Fish species & No of samples & $\begin{array}{c}\text { Histamine level } \\
(\mathbf{m g} / \mathbf{k g})\end{array}$ & $\begin{array}{c}\text { Interval of variation } \\
(\mathbf{m g} / \mathbf{k g})\end{array}$ \\
\hline Tuna & 544 & $15.03 \pm 1.73^{\mathrm{a}, \mathrm{x}}$ & $2.90-68.00$ \\
Sardine & 378 & $50.27 \pm 9.20^{\mathrm{a}, \mathrm{y}}$ & $3.50-264.50$ \\
Mackerel & 108 & $110.6 \pm 17.82^{\mathrm{b}, \mathrm{y}}$ & $6.80-365.50$ \\
\hline Total & 1030 & $44.96 \pm 5.29$ & $2.90-365.50$ \\
P value (ANOVA) & & $<0.0001$ &
\end{tabular}

Values are expressed as mean $\pm S d$

${ }^{a}$ Means with same superscript within the column differ significantly at $P<0.001$

${ }^{x, y}$ Means with same superscript within the column differ significantly at $P<0.0001$ 
histamine. Additionally, they reported the higher levels of histamine in frozen fish compared to canned fish.

In our trial, the levels of histamine were higher in the canned fish samples compared to the frozen fish. Histamine is formed by histidine decarboxylation, under the activity of histidine decarboxylase enzyme. Thus, for histamine formation it is necessary the presence of available histidine and enzyme forming bacteria along with favorable conditions for their activity.

One of the factors that affect the activity of histidine decarboxylase is temperature. The enzyme activity increased with increasing temperature to $30-40{ }^{\circ} \mathrm{C}$ and decreased above $50{ }^{\circ} \mathrm{C}$. In the canned fish, higher temperature during processing might have decreased the enzyme activity. Although histidine decarboxylase activity decreased at high temperature, histamine production would continue until the enzyme became inactive i.e. the histamine in fish meat would accumulate during heat treatment until the enzyme was inactive (Kanki et al.,2007, Chung et al., 2017).

The higher level of histamine in canned fish could be the consequence of protein degradation after thermal process, which elevates the amount of free histidine. Histamine is heat resistant, and once formed it remains integral regardless to applied thermal process. Therefore, high concentration of histamine in canned fish is most likely the consequence of recontamination with the histidine decarboxylase forming bacteria during processing of fish (FDA, 2011).

Heat treatment has a different effect to histamine concentration regarding to the type of treatment applied. Research data about the effects of different cooking methods on histamine concertation showed the increase of histamine concentrations after grilling or frying, but boiling had little effect on histamine levels in fish meat. The authors believe that the reason for these changes may be the moisture evaporation during grilling or frying, which elevates the histamine concentration (Chung et al., 2017). Adams et al. (2018) proved that the process of precooking during the production of canned tuna or frozen tuna suppresses the formation of histamine for $12 \mathrm{~h}$ or longer after precooking. Thus, it would be of interest to compare the fish products regarding to differences in the production process.

\section{Distribution of histamine in the fish samples}

Distribution of histamine concentrations in frozen fish samples showed that there were no samples with very high levels of histamine (above the $50 \mathrm{mg} / \mathrm{kg}$ ) (Table 3).

The largest number of samples contained histamine below LOD $(61.67 \%$ of total number of samples).

Table 3.

Distribution of histamine in frozen fish samples

\begin{tabular}{lcccccc}
\hline Sample & \multicolumn{7}{c}{$\begin{array}{c}\text { Histamine content } \\
(\mathbf{m g} / \mathbf{k g})\end{array}$} \\
& $\mathbf{2 , 5}$ & $\mathbf{2 , 5 - 5}$ & $\mathbf{5 - 1 0}$ & $\mathbf{1 0 - 5 0}$ & $\mathbf{5 0 - 1 0 0}$ & $>\mathbf{1 0 0}$ \\
\hline Tuna & 37 & 13 & 6 & 1 & - & - \\
Sardine & 12 & 3 & 11 & 2 & - & - \\
Mackerel & 21 & 3 & 4 & 5 & - & - \\
Sprat & 33 & 10 & 5 & 1 & & \\
\hline
\end{tabular}

Table 4.

Distribution of histamine in canned fish samples

\begin{tabular}{lcccccc}
\hline Sample & \multicolumn{7}{c}{$\begin{array}{c}\text { Histamine content } \\
(\mathbf{m g} / \mathbf{k g})\end{array}$} \\
& $<\mathbf{2 , 5}$ & $\mathbf{2 , 5 - 5}$ & $\mathbf{5 - 1 0}$ & $\mathbf{1 0 - 5 0}$ & $\mathbf{5 0 - 1 0 0}$ & $>\mathbf{1 0 0}$ \\
\hline Tuna & 456 & 20 & 20 & 39 & 9 & - \\
Sardine & 315 & 13 & 11 & 22 & 7 & 10 \\
Mackerel & 73 & - & 5 & 5 & 10 & 15 \\
\hline
\end{tabular}


In the samples of canned fish, the smalllest number of samples had histamine concentrations above $100 \mathrm{mg} / \mathrm{kg}$ (Table 4 ), and the highest below LOD (84.14\% of total number of samples). High histamine concentration is an indicator of decomposition of fish (FDA, 1995). Dimitrijević et al. (2016) found histamine amounts below LOD in $45.93 \%$, but the LOD in this trial was $5 \mathrm{mg} / \mathrm{kg}$.

The acceptable concentrations of histamine in fish meat differ among countries. The US FDA established a hazard action level of $50 \mathrm{mg} / \mathrm{kg}$ for scombroid or scombroid like fish (FDA, 1995).

The overall mean of histamine levels in all samples of frozen fish was below the international standard of $50 \mathrm{mg} / \mathrm{kg}(9.85$ $\mathrm{mg} / \mathrm{kg}$ ). In this study, the mean value for canned fish was above the limit of 50 $\mathrm{mg} / \mathrm{kg}(58.63 \mathrm{mg} / \mathrm{kg})$. The samples with histamine levels above the FDA hazard action level were of all analyzed species (canned tuna, canned sardine and canned mackerel).

The Council directive of European Union has specified the permissible contents of histamine in fish and Serbia has adopted and harmonized its regulations with the EU polices. According to this regulation, nine subunits of each sample are to be taken from each batch.

Samples must comply with the following requirements: the mean of histamine concentration in all subunits must not exceed $100 \mathrm{mg} / \mathrm{kg}$; two subunits may have a value of more than $100 \mathrm{mg} / \mathrm{kg}$ but less than $200 \mathrm{mg} / \mathrm{kg}$; no subunit may have a value above $200 \mathrm{mg} / \mathrm{kg}$.

Regarding to regulation only three out of all samples were not acceptable, and these were the samples of canned sardine and canned mackerel. Two samples of canned sardine were declared unsafe for human consumption. In one sample, two of nine subunits had histamine concentration between 100 and $200 \mathrm{mg} / \mathrm{kg}$, and, in two subunits of the same sample, histamine was above $200 \mathrm{mg} / \mathrm{kg}$. The other sample that was declared unsafe for human health contained $>250 \mathrm{mg} / \mathrm{kg}$ histamine in four sample subunits whe- reas in two subunits, histamine ranged between 100 and $200 \mathrm{mg} / \mathrm{kg}$. In one sample of canned mackerel histamine concentration was above the legal limit. Two subunits of this sample contained above 300 $\mathrm{mg} / \mathrm{kg}$ histamine and five subunits had between 100 and $200 \mathrm{mg} / \mathrm{kg}$ histamine (Commission Regulation 2073/2005/EC, Pravilnik SI.GI.RS 72/2010 I SI.GI.RS 62/18).

These results are in accordance with Dimitrijević et al. (2016) who reported histamine level above legal limit in only one sample (6.67\%). Danilović et al. (2017) stated about levels of histamine below the allowed value. Babić et al. (2015) and Kalantari et al. (2015) reported histamine levels above EU and Serbian regulatory limits in $3.09 \%$ and $0.79 \%$ of examined samples, respectively.

High level of compliance with regulation point out the adequate implementation of control and supervising of products placed on Serbian market, as well as the importance of principles of good hygienic and manufacturing practice in order to produce safe product.

\section{CONCLUSIONS}

This report pointed out the relatively low level of histamine in frozen and canned fishes sold on Serbian market, with only three samples were not in accordance with legal limit for histamine, which confirmed good quality of commercially available fish. Higher histamine concentrations were observed in canned fish than in frozen one. Very few samples with histamine levels above the legal limit implied to adequate implementation of measures for preventing and controlling the histamine forming bacteria and consequently the histamine levels in food. Continuing reports about histamine level in fish present on the market can improve the insight into the efficacy of the production process and quality supervision system in the country.

\section{REFERENCES}

1. Adams , F., Nolte, F., Colton, J., Debeer, J., Weddig, L. (2018). Precooking as a control for histamine formation during the processing of tuna: An industrial process validation. Journal of Food Protection, 81 (3), 444-455. 
2. Auerswald, L., Morren, C., Lopata, A.L. (2006). Histamine levels in seventeen species of fresh and processed South African seafood. Food Chemistry, 98, 231-239.

3. Babić, J., Petrović, J., Kartalović, B., Pelic, M., Jakšić, S., Ćirković, M. (2015). The importance of border inspection in control histamine poisoning from canned tuna, VII International Conference "WATER \& FISH", June, 10-12. Faculty of Agriculture, Belgrade, Serbia, Proceedings, pp.165-169.

4. Chung, B.Y., Park, S.Y., Byun, S.Y., Son, J.H., Choi, Y.W, Cho, Y.S., Kim, H.O., Park, C.W. (2017). Effect of different cooking methods on histamine levels in selected foods. Annals of Dermatology, 29 (6), 706-714.

5. Commission Regulation (EU) No. 2073/2005/EC (2005). Official Journal, L 338/1.

6. Danilović, B., Potić, V., Stamenković, S., Savić, D. (2017). A review of the presence of some food contaminants on the territory of the Republic of Serbia. Advanced Technologies, 6 (2), 84-95.

7. Dimitrijevic, M., Stefanovic, S., Karabasil, N., Vasilev, D., Cobanovic, N., Ilic, N., Djordjevic, V. (2016). UPLC-MS/MS determination of histamine levels in canned fish collected from Belgrade retail markets. Meat Technology, 57 (1), 47-56.

8. FDA (2011). Guidance for the Industry: Fish and Fishery Products Hazards and Controls Guidance, Fourth Edition, Food and Drug Administration, US, 13-14.

9. FDA (1995). Decomposition and histamine Raw, frozen tuna and mahi-mahi, canned tuna, and related species, revised compliance guide, availability. Federal Registration, 149, 3975439756.

10. GrafPad Prism software (2012).v.6.00/a, Graph Pad Software Inc., San Diego, CA, USA.

11. Kaufman A., Maden, K. (2017). Easy and fast method for the determination of biogenic amines in fish and fish products with liquid chromatography coupled to Orbitrap tandem mass spectrometry. Journal of AOAC international, 101 (2), 336-341.

12. Kalantari, H., Behfar, A.A., Nazari, Z., Kalatari, M., Hosseini, H. (2015). Occurrence of histamine in canned tuna fish produced of two major manufactories in Khuzestan province by HPLC method. International Journal of Current Re- search Chemistry and Pharmacy Science, 2 (10), 9-15.

13. Kanki, M., Yoda, T., Tsukamoto, T., Baba, E. (2007). Histidine decarboxylases and their role in accumulation of histamine in tuna and dried saury. Applied and Environmental Microbiology, 73, 1467-1473.

14. Lehanea, L., Olleyb, J. (2000). Histamine fish poisoning revisited. International Journal of Food Microbiology 58, 1-37.

15. Li, Q., Lv, J., Zhang, L., Dong, Z., Feng, L., Luo, Y. (2017). Biogenic amines and predictive models of quality of rainbow trout (Oncorhynchus mykiss) fillets during storage. Journal of Food Protection, 80 (2), 279-287.

16. Yesudhason, P., Al-Zidjali, M., Al-Zidjali, A., AlBusaidi, M., Al-Waili, A., Al-Mazrooei, N., AlHabsi, N.S. (2013). Histamine levels in commercially important fresh and processed fish of Oman with reference to international standards. Food Chemistry, 140, 777-783.

17. Vaciana-Nouges, M.T., Vidal-Carou, M.C., Marine-Font, A. (1997). Biogenic amines in fresh and canned tuna. Effect of canning on biogenic amines contents. Journal of Agricultural and Food Chemistry, 45, 4324-4328.

18. Özogul, F., Öztekin, R., Kulawik, P. (2017). Biogenic amine formation and microbiological quality of anchovy (Engraulis encrasicolus) treated with lavender and lemon balm ethanol extracts. Journal of Food Science, 82 (5), 1278-1284, DOI: 10.1111/1750-3841.13704.

19. Pravilnik (2010). Pravilnik o opštim i posebnim uslovima higijene hrane u bilo kojoj fazi proizvodnje, prerade i prometa. Službeni glasnik RS, 72/2010.

20. Pravilnik (2018). Pravilnik o izmenama i dopunama pravilnika o opštim i posebnim uslovima higijene hrane u bilo kojoj fazi proizvodnje, prerade i prometa. Službeni glasnik RS, 62/18.

21. Rahimi, E., Nayebpour, F., Alian, F. (2012). Determination of histamine in canned tuna fish using ELISA method. American-Eurasian Journal of Toxicological Sciences, 4 (2), 64-66.

22. Test Instruction HIS-EO01 (2008). Enzyme Immunoassay for the Quantitative Determination of Histamine in Food, Cat.No. HISE01, Version January $2^{\text {nd }}$, Immunolab $\mathrm{GmbH}$, Germany. 


\section{ХИСТАМИН У РИБИ ДОСТУПНОЈ НА ТРЖИШТУ СРБИЈЕ у 2018. години}

Марија С. Павловић* ${ }^{1}$, Снежана Д. Ивановић ${ }^{1}$, Иван Н. Павловић ${ }^{1}$, Никола И. Роквић $^{1}$, Владимир И. Радосављевић ${ }^{1}$, Драган Д. Василев ${ }^{2}$

${ }^{1}$ Научни институт за ветеринарство Србије, 11000 Београд, Војводе Тозе 14, Србија ${ }^{2}$ Универзитет у Београду, Факултет ветеринарске медицине, Катедра за хигијену и технологију намирница анималног порекла, 11000 Београд, Булевар ослобођења 18, Србија

Сажетак: Хистамин је биоактивни амин, који настаје у реакцији декарбоксилације аминокиселине хистидина, под дејством ензима L- хистидин декарбоксилазе. Висок ниво слободног хистидина у месу рибе, активност ензим продукујућих бактерија и високе температуре складиштења делују предиспонирајуће на синтезу хистамина. Међу најзначајније факторе који утичу на концентрацију хистамина у месу рибе јесу врста рибе и метод њеног конзервисања. У циљу утврђивања ове зависности, узорци замрзнуте рибе (туне, скуше, сардине и папалине) и рибе у конзерви (туне, сардине и скуше) су анализирани ЕЛИСА методом. Утврђене су ниже концентрације хистамина у узорцима замрзнуте рибе (од 5.71 мг/кг до $18.03 \mathrm{mr} / к г$ ) у поређењу са конзервама од рибе (од $15.03 \mathrm{mг/кг} \mathrm{до} 110.6 \mathrm{mг/кг).} \mathrm{Највише}$ концентрације хистамина су установљене у узорцима скуше, без обзира на метод конзервисања (110.6 мг/кг у конзервама од скуше и 18.03 мг/кг у замрзнутој скуши), које су биле и статистички значајно веће у односу на конзерве туне и конзерве сардине ( $<<0.0001)$. Од укупног броја узорака, само три узорка (два узорка сардине у конзерви и један узорак скуше у конзерви) су проглашени небезбедним за здравље људи. У највећем броју испитаних узорака измерене су релативно ниске концентрације хистамина, што указује на адекватно спровођење контроле и надзора над производима који се пласирају у промет на српском тржишту.

Кључне речи: хистамин, риба, конзерве од рибе, замрзнута риба

Received: 3 December 2018

Received in revised form: 28 December 2018

Accepted: 24 January 2019 